Egyptian J. of Nutrition Vol. XXXIII No. 1 (2018)

\title{
The Effect of Some levels of Marjoram and its Extracts on Liver Cancer Incident by Benzopyrene in Rats
}

\author{
Aisha K. Abass, Mohammed M. El-Sayed, Sherif S. \\ Rageb.
}

Department of Nutrition and Food Science, Faculty of Home Economics, Menoufia University, Shebin El- Kom , Egypt

\begin{abstract}
This study was conducted to investigate the effect of some Marjoram extracts on Liver Cancer incident by Benzopyrene in Rats. Fourty-eight a dult male albino rats weigheing 170-190 g were used in this study, and divided into two main groups. First group (6 rats) fed on basal diet as control (-), second group was induced liver cancer by Benzopyrene (100 mg/5 ml/kg body weight) dissolved in $0.9 \% \mathrm{NaCl}$ solution containing $0.1 \%$ Tween 20 , Liver cancer rats groups and divided into 7 groups, per each one of them were liver cancer control positive. While the other six groups were divided into three groups fed a basal diet and give it Marjoram methanol extract 5 $\mathrm{ml}$ on every day in orel and other three groups fed on basel diet after replacing $0.5,1$ and 2\% Marjoram powder and feeding continued for 45 days. After the treatment, body weight gain (B.W.G and B.W.G\%), feed intake (FI), feed efficiency ratio (FER) and blood samples were measured and serum,(GOT),(GPT) , ALP, Albumin , Alpha-fetoprotein , Glutathione (GSH) and Malondialdehyde (MDA) levels were determined, and Histopathological structure of liver has
\end{abstract}




\section{Aisha K . Abass, Mohammed M. El-Sayed, Sherif S. Rageb.}

been evaluated. The obtained results revealed that feeding on Marjoram extracts caused a significant $(P \leq 0.05)$ improvements in body weight gain (B.W.G\%) , FER, liver functions, Alpha-fetoprotein , Glutathione (GSH) and Malondialdehyde (MDA) as compared with control (+ve) group .

Histopathological investigations confirmed the biochemical changes in rats serum . It could be concluded that marjoram was effective in protecting against liver cancer rats not only decreased the level of liver functions but also has beneficial effect on serum Alphafetoprotein , Glutathione (GSH) and Malondialdehyde (MDA) .Therefore, obtained data recommended this tested Marjoram extract and dry Marjoram by a moderate amount $(0.75 \%$ and $2 \%)$ to be included in our daily drinks and dishes.

\section{Introduction}

Cancer begins when cells in a part of the body start to grow out of control. There are many kinds of cancer, but they all start because of out-of-control growth of abnormal cells. Cancer cell growth is different from normal cell growth. Instead of dying, cancer cells continue to grow and form new, abnormal cells. Cancer cells can also invade (grow into) other tissues, something that normal cells cannot do. Growing out of control and invading other tissues are what makes a cell a cancer cell. In most cases the cancer cells form a tumor like liver cancer (Howlader et al., 2012). Hepatocellular cancer (HCC) can have different growth patterns like: Some begin as a single tumor that grows larger. Only late in the disease does it spread to other parts of the liver. The second type seems to start as many 


\section{Egyptian J. of Nutrition Vol. XXXIII No. 1 (2018)}

small cancer nodules throughout the liver, not just a single tumor. This is seen most often in people with cirrhosis (chronic liver damage) (American Cancer Society, 2013). Hepatocellular carcinoma (HCC) is one of the most common malignant tumors in the world, representing the third leading cause of death from cancer (Bosch et al., 1999 ; El-Serag, 2011) and the fifth most prevalent malignancy worldwide (Farazi and Depinho, 2006).

Owing to advances in diagnostics and therapeutics, HCC can be creatively treated when detected at an early stage by applying therapies including radiofrequency ablation (RFA), transcatheter arterial chemoembolization (TACE) and surgical resection. However, curative treatments are often hampered by frequent recurrence of HCC (Okuda ,2007). Because the remaining liver retains the potential for de novo carcinogenesis (Kumada et al.,1997). Although systemic chemotherapy has also been challenged to patients with advanced stages of HCC, it is mostly ineffective (Thomas ,2008).

Marjoram, sweet "Origanum marjorana, (Linn.)", family of Labiatae is well known as herbs in world's herbal medicine including Egypt. Dried leaves represent the main part used in medicinal purposes of this herb. This herb exhibit a wide range of properties/therapeutic effects include stimulant, carminative, diaphoretic and mildly tonic; a useful emmenagogue. In the commencement of measles, it is useful in producing a gentle perspiration and bringing out the eruption, being given in the form of a warm infusion, which is also valuable in spasms, colic, and to give relief from pain in dyspeptic complaints. Externally, the dried leaves and tops may be applied in bags as a hot fomentation to painful swellings and rheumatism, as well as for colic. An infusion made from the fresh plant will relieve nervous headache, by virtue of the 


\section{Aisha K. Abass, Mohammed M. El-Sayed, Sherif S. Rageb.}

camphoraceous principle contained in the oil . All of these therapeutic effects principally attributed to the key constituents i.e. essential oils, terpenes and phenolics in the standardized extract of herb (Charai et al., 1996; Vera and Chane, 1999; Novak et al., 2002 and Miguel et al., 2003). Amongst of different types of compounds, phenolic compounds have been occupied the central position.

The phenolic constituents were importance in herbs exhibit a wide range of biological effects, including antioxidant, anticarcinogenic and aantibacterial (Majid et al., 1991; Harttig et al., 1996 ; Ghaly, 2004 and El-Safty, 2008).

Benzo(a)pyrene $[\mathrm{B}(\mathrm{a}) \mathrm{P}]$ is a member of the family, polycyclic aromatic hydrocarbon (PAH) that is a by-product of incomplete combustion or burning of organic (carbon-containing) items, e.g., cigarettes, gasoline, and wood. $\mathrm{B}(a) \mathrm{P}$ is commonly found with other PAHs in cigarette smoke, in grilled, fryed and broiled foods, and as a by-product of many industrial processes (Elhassaneen, 2004). B(a)P is also found in ambient (outdoor) air, indoor air, and in some water sources (U.S. Environmental Protection Agency, 2005). Many of $\mathrm{PAH}$ compounds including $\mathrm{B}(\mathrm{a}) \mathrm{P}$ have been shown to be toxic, mutagenic and/or carcinogenic by extensive experiments in vivo and in vitro systems (Harvey, 1985; Hawkins et al., 1990 ; Elhassaneen, 1996 and Elhassaneen, 2002 ). It is known that the toxic, tumorigenic and carcinogenic effects of $\mathrm{B}(\mathrm{a}) \mathrm{P}$ correlate with the cellular metabolism of this compounds to arene oxides, phenols, quinones, dihydrodiols, and epoxides and with their subsequent formation of recative intermediates that interact covalently with DNA to form adducts (Harvey, 1982 and Elhassaneen, 1996). According to the knowledge and science, the studies regarding the potential 


\section{Egyptian J. of Nutrition Vol. XXXIII No. 1 (2018)}

effects of marjoram on liver disease/cancer are so limited. Therefore, in this study, the influence of Marjoram on the liver cancer of rats induced by benzo(a)pyren will be study.

Thereupon,the effect of some levels of Marjoram powdered and its extracts on Liver Cancer induced by Benzopyrene in Rats were studied.

\section{Materials and Methods}

\section{Materials:}

Marjoram, sweet "Origanum marjorana, (Linn.)" samples were obtained from Bani Mazar city, Minia Governorate, Egypt.

Throughout this study, a SP Thermo Separation Products Liquid Chromatograph (Thermo Separation products, San Jose, CA) was used with a Consta Metvic 4100 pump, a Spectra Series AS100, Spectra System UV 1000 UV/Visible Spectrophotometer Detector, Spectra System FL 3000 and a PC 1000 system software.The columns used (Alltech, Deerfield, IL, USA) for a Spherosorb ODC-2 $(5 \mu \mathrm{m}, 150 \times 4.6 \mathrm{~mm}$ I.d.) for glutathione fractions.

\section{Marjoram drying process}

After arriving of the Marjoram samples, it were prepared for drying process such as mentioned by El-Safty, (2008). Samples were subjected to manual sorting, washing and drying at $50{ }^{\circ} \mathrm{C}$ until arriving by the moisture in the final product to about $8 \%$. The dried Marjoram samples were put in polyethylene bags and packed in cartoon boxes until chemical and microbiological analysis process. 


\section{Aisha K. Abass, Mohammed M. El-Sayed, Sherif S. Rageb .}

\section{Biological Experiments}

\section{Animals}

Animals used in this study, adult male albino rats $(170-190 \mathrm{~g}$ per each) were obtained from Helwan Station, Ministry of Health and Population, Helwan, Cairo, Egypt.

\section{Basal Diet:}

The basic diet prepared according to the following formula as mentioned by $\boldsymbol{A I N}$, (1993) as follow: protein (10\%), corn oil (10\%), vitamin mixture $(1 \%)$, mineral mixture $(4 \%)$, choline chloride $(0.2 \%)$, methionine $(0.3 \%)$, cellulose $(5 \%)$, and the remained is corn $\operatorname{starch}(69.5 \%)$.

The used vitamin mixture component was recommended by Campbell, (1963), while the salt mixture used was formulated according to Hegsted et al., (1941).

\section{Experimental design}

All biological experiments performed a complied with the rulings of the Institute of Laboratory Animal Resources, Commission on life Sciences, National Research Council (NRC, 1996). Rats ( $\mathrm{n}=$ 48 rats), 170 - $190 \mathrm{~g}$ per each, were housed individually in wire cages in a room maintained at $25 \pm 2{ }^{\circ} \mathrm{C}$, relative humidity (55 $\pm 5 \%$ ), a 12-hr lighting cycle and kept under normal healthy conditions. All rats were fed on basal diet for one-week before starting the experiment for acclimatization. After one week period, the rats were divided into two main groups, the first group (Group 6 rats, as a negative control group) still fed on basal diet and the other main group (42 rats) was were challenged with an ip injection of B[a]P $(100 \mathrm{mg} / 5 \mathrm{ml} / \mathrm{kg}$ body weight) dissolved in $0.9 \% \mathrm{NaCl}$ solution containing $0.1 \%$ Tween 20 to 
Egyptian J. of Nutrition Vol. XXXIII No. 1 (2018)

induce liver impaired rats then classified into eight sub- groups as follow:

- Group (2): fed on standard diet only as a positive control (rats with liver Cancer) .

- Group (3): fed on standard diet containing $0.25 \%$ Marjoram methanol extract (MME)

- Group (4): fed on standard diet containing 0.50\% MME .

- Group (5): fed on standard diet containing $0.75 \% \mathrm{MME}$.

- Group (6): fed on standard diet containing $0.5 \%$ Dry Marjoram (DM).

- Group (7): fed on standard diet containing $1 \%$ DM.

- Group (8): fed on standard diet containing $2 \%$ DM.

\section{Blood sampling}

At the end of experiment period, 45 days, blood samples were collected after 12 hours fasting using the abdominal aorta and rats were scarified under ether anesthetized. Blood samples were received into clean dry centrifuge tubes and left to clot at room temperature, then centrifuged for 10 minutes at $3000 \mathrm{rpm}$. Serum was carefully aspirate, transferred into clean covet tubes and stored frozen at $-20^{\circ} \mathrm{C}$ until analysis . Rats were there after opened, liver, kidneys, spleen, heart, and lungs removed and washed in saline solution, then dried by Whitman peper and weighted. Relative weights of mentioned organs were calculated using the following formula. 


\section{Aisha K. Abass, Mohammed M. El-Sayed, Sherif S. Rageb.}

\section{Biological evaluation}

During the period of the experiment, all rats were weight once a week and the consumed diets were recorded everyday (daily feed intake ).At the end of the experiment, biological evaluation of the experimental diets was carried out by determination of body weight gain (BWG) and feed efficiency ratio (FER).

$B W G=$ Final weight - Initial weight .

B.W.G \% $=$ (Final Weight_Initial Weight) $/$ Initial Weight $\times 100$

F.E.R = Body Weight Gain (g)/ Feed Intake (g) .

\section{Hematological analysis}

Different tested parameters in serum were determination using specific methods follow: Serum glutamate oxaloacetate transaminase S.GOT according to Henry, (1974) and Yound, (1975), Serum glutamate pyruvic transaminase S.GPT according to Yound,(1975), serum alkaline phosphatase (ALP) according to IFCC, (1983) , serum Albumin according to Durpt, (1974). Serum Glutathione according to Mcfarris and Reed, (1987). serum Malonaldialdehyde according to Buege and Aust, (1978).

\section{Histopathological Examination:}

At the end of the experiment which continued for 30 successive days, all rats were sacrificed, tissue samples including liver was taken for histopathological examination according to Drury and Wallington (1980).

\section{Statistical Analysis}

statistical analysis were performed by using computer program statistical package for social science SPSS, (1998), and compared with each other using the suitable tests. 
Egyptian J. of Nutrition Vol. XXXIII No. 1 (2018)

\section{Results}

\section{Biological changes:}

Effect of some levels of MME and DM on nutritional parameters of rats suffering from liver cancer :

Table(1) Showed B.W.G, B.W.G(\%), (F.I) and (F.E.R) of negative control, positive control and liver cancer treated groups with $(0.25 \%, 0.50 \%$ and $0.75 \%) \mathrm{MME}$ and $(0.5 \%, 1 \%$ and $2 \%) \mathrm{DM}$. As shown the mean value of (B.W.G) and (B.W.G\%) of liver cancer treated groups $(0.25 \%, 0.50 \%$ and $0.75 \% \mathrm{MME})$ and $(0.5 \%, 1 \%$ and $2 \% D M)$ were significantly increase ( $p \leq 0.05)$ comparing with positive control. and was low when compared with negative control. Results show that the mean value of FI of treated groups were nonsignificantly changes, comparing with control (+) group. Data show that the mean value of FER of liver cancer treated groups fed on various diets were increased significantly $(p \leq 0.05)$ except rats group which fed on $(0.25 \% \mathrm{MME})$ which showed nonsignificant differences, comparing with control (+) group.

\section{Biochemical changes:}

Effect of MME and DM on serum liver functions of liver cancer rats:

Table(2) result show the effect feeding on different levels of MME and DM on serum GPT,GOT,ALP and Albumin . As shown in the table the lowest mean values of GPT were found for MME $(0.75 \%)$ followed by MME $(0.50 \%)$ and DM $(2 \%)$ groups respectively. Lowest GOT value was found for treatment MME $(0.75 \%)$ followed by DM (2\%) and MME (0.50\%) groups respectively . The lowest ALP was found for MME $(0.75 \%$ \& $0.50 \%)$ groups. Anyhowe, the lowest Albumin value was recorded for MME (0.75\%) ,and DM (2\%) diets as 


\section{Aisha K. Abass, Mohammed M. El-Sayed, Sherif S. Rageb.}

compared with that found for liver cancer control (+ve) group , indicating the improvement of the liver functions .

Effect of MME and DM on serum Alpha-fetoprotein, Glutathione (GSH) and Malondialdehyde (MDA) liver cancer rats.

Table(3) the result show the effect of feeding on different levels of MME and DM on serum Alpha-fetoprotein, Glutathione and Malondialdehyde. As shown in the table, the mean value of Alpha-fetoprotein of liver cancer treated groups fed on various diets were significantly lower $(p \leq 0.05)$ comparing with positive control. The same table illustrated that the mean value of GSH of liver cancer treated groups fed on various diets.

Results show that the mean value of GSH of treated groups were nonsignificantly change, except group of rats which fed on ( $0.75 \% \mathrm{MME}$ and $2 \% \mathrm{DM}$ ) were a significantly comparing with control (+) group. As for as, the mean value of MDA of liver cancer treated groups fed on various diets, Results show that the mean value of MDA of treated groups were decreased significantly, except rats group which fed on $(0.50 \% \mathrm{DM})$ were nonsignificantly comparing with control (+) group .

\section{Conclusion}

Marjoram methanol extract and dry marjoram (Origanum marjorana) were effective in protecting against liver cancer rats not only decreased the level of serum liver functions but also has beneficial effect on Alpha-fetoprotein , Glutathione (GSH) and Malondialdehyde (MDA) Therefore, we recommended this tested 


\section{Egyptian J. of Nutrition Vol. XXXIII No. 1 (2018)}

plant by a moderate amount $(0.75 \%$ MME and $2 \% \mathrm{DM})$ to be included in our daily drinks.

\section{Discussion}

The present results showed a significant difference in body weight gain and Feed efficiency ratio between the different treatment groups . on the other hand, the present study showed no significant difference in feed intake between treatment groups on Marjoram compared with control (+ve) group. This was in agreement with the results of (Novak et al., 2002) who reported that body weight $\%$ and FER , consequently the mean value of body weight $\%$ and FER for the control (+ve) group showed a significant difference as compared to the negative control group .

Results in this study showed a significant difference in (GPT, GOT, ALP, Albumin) between the different treatment groups on Marjoram compared with control (+ve) group. These result were in parallel with that of (Miguel et al., 2003) who reported that the increase of GPT and GOT are closely correlated in most cases with liver diseases. The findings indicated that there was high incidence of liver damage as result of changed by injection of BP which in turn affect liver function. Anyhow, lowest GPT, GOT,ALP and Albumin were recorded for treatment groups $(0.75 \% \mathrm{MME})$ and $(2 \% \mathrm{DM})$ diets as compared with control (+ve) group, indicating improvement of the liver functions .

Results in this study showed a significat difference in Alphafetoprotein between all liver cancer rats fed on treatment groups compared with control (+ve) group .The mean values of Glutathione (GSH) showed no significant differences between the different 


\section{Aisha K . Abass, Mohammed M. El-Sayed, Sherif S. Rageb.}

treatment groups, except rats group (0.75\%MME and $2 \% \mathrm{DM})$ showed a significant difference as compared with control (+ve) group

The mean values of Malonaldialdehyde (MDA) showed a significant differences in liver cancer rats fed on treatment groups, except rats group $(0.25 \% \mathrm{MME}$ and $0.5 \% \mathrm{DM})$ showed no significant differences as compared with control (+ve) group. This was in agreement with the results of (Ibrahim et al., 2007) who reported there were a significant differences in the GSH level in the methanoltreated group compared control group, the levels of liver MDA and GSH are shown the ethanol-treated group had a significantly differences MDA levels compared to control, both plant extracttreated group showed a trend to lower MDE.

\section{Histopathological changes}

Microscopically, liver of rat from control negative group showed the normal histological structure of hepatic lobule (picts. 1 \& 2). Meanwhile, liver of rats from control positive group revealed hydropic degeneration of hepatocytes (pict. 3), fibroplasia in the portal triad (pict. 4) and portal infiltration with mononuclear inflammatory cells (pict. 5). However, liver of rats from group 1 which treated with $0.25 \% \mathrm{MME}$ revealed no histopathological changes (pict. 6) except slight Kupffer cells activation in some examined sections (pict. 7). Moreover, liver of rats from group 2 which treated with 0.50\% MME showed portal infiltration with inflammatory cells (Fig. 8) and Kupffer cells activation (pict. 9). Examined sections from group 3 which treated with $0.75 \%$ MME showed no histopathological changes (pict. 10) except cytoplasmic vacuolization of some hepatocytes in 
some sections (pict. 11). cytoplasmic vacuolization of centrilobular hepatocytes was the only change observed in liver of rats from the group 4 treated with $0.5 \% \mathrm{DM}$ (picts. $12 \& 13$ ). Moreover, liver of rats from group 5 which treated with 1\% DM showed no histopathological changes (pict. 14) except slight activation of Kupffer cells (pict. 15). Liver of rats from group 6 which treated with $2 \%$ DM revealed Kupffer cells activation (pict. 16) and slight dilatation of hepatic sinusoids (pict. 17). 


\section{Aisha K . Abass, Mohammed M. El-Sayed, Sherif S. Rageb .}

Taple(1): Mean value of (B.W.G(g) and B.W.G\%), (F.I) and ratio (F.E.R) of liver cancer rats:

\begin{tabular}{l|c|c|c|c}
\hline \multicolumn{1}{c|}{ Parameters } & B.W.G(g) & B.W.G(\%) & F.I $(\mathrm{g})$ & F.E.R \\
\hline Control(-) & $55.5^{\mathrm{a}} \pm 1.32$ & $34.52^{\mathrm{a}} \pm 1.33$ & $20.8^{\mathrm{ab}} \pm 1.29$ & $2.7^{\mathrm{a}} \pm 0.22$ \\
Control(+) & $26.75^{\mathrm{g}} \pm 0.62$ & $14.62^{\dagger} \pm 0.45$ & $22.5^{\mathrm{ab}} \pm 1.29$ & $1.2^{\mathrm{a}} \pm 0.09$ \\
$0.25 \% \mathrm{MME}$ & $33.5^{\mathrm{et}} \pm 0.28$ & $18.37^{\mathrm{e}} \pm 0.85$ & $23.1^{\mathrm{ab}} \pm 1.29$ & $1.45^{\mathrm{cd}} \pm 0.64$ \\
$0.50 \% \mathrm{MME}$ & $39.75^{\mathrm{a}} \pm 1.03$ & $22.17^{\mathrm{cd}} \pm 0.70$ & $23^{\mathrm{ab}} \pm 0.95$ & $1.75^{\mathrm{bc}} \pm 0.86$ \\
$0.75 \% \mathrm{MME}$ & $50.5^{\mathrm{b}} \pm 0.50$ & $26.85^{\mathrm{b}} \pm 0.23$ & $24.3^{\mathrm{a}} \pm 1.29$ & $2.07^{\mathrm{b}} \pm 0.85$ \\
$0.5 \% \mathrm{DM}$ & $31.5^{\dagger} \pm 1.50$ & $18.07^{\mathrm{e}} \pm 1.03$ & $19.6^{\mathrm{b}} \pm 1.29$ & $1.62^{\mathrm{c}} \pm 0.11$ \\
$1 \% \mathrm{DM}$ & $35.75^{\mathrm{e}} \pm 1.43$ & $20.37^{\mathrm{de}} \pm 0.94$ & $21.7^{\mathrm{ab}} \pm 1.29$ & $1.65^{\mathrm{c}} \pm 0.86$ \\
$2 \% \mathrm{DM}$ & $43.75^{\mathrm{c}} \pm 0.25$ & $34.52^{\mathrm{a}} \pm 1.33$ & $20.8^{\mathrm{ab}} \pm 1.29$ & $2.7^{\mathrm{a}} \pm 0.22$ \\
\hline
\end{tabular}

Values are expressed as, Means \pm SE ; Means in the same column each group with different superscript letters are significantly difference $(p \leq 0.05)$

Taple (2) :Effect of MME and DM on serum GPT , GOT and ALP of liver cancer rats:

\begin{tabular}{c|c|c|c|c}
\hline Parameters & S.GPT(U/L) & S.GOT(U/L) & ALP(U/L) & Albumin(g/dl) \\
\hline Control(-) & $40.25^{\mathrm{a}} \pm 2.28$ & $41.5^{\mathrm{a}} \pm 1.32$ & $189.5^{\mathrm{t}} \pm 2.46$ & $3.52^{\mathrm{a}} \pm 0.21$ \\
Control(+) & $101.25^{\mathrm{a}} \pm 4.11$ & $108.25^{\mathrm{a}} \pm 1.49$ & $385^{\mathrm{a}} \pm 4.52$ & $7.35^{\mathrm{a}} \pm 0.29$ \\
$0.25 \% \mathrm{MME}$ & $87.75^{\mathrm{bc}} \pm 1.25$ & $92.5^{\mathrm{c}} \pm 1.70$ & $257.25^{\mathrm{c}} \pm 4.88$ & $5.92^{\mathrm{b}} \pm 0.13$ \\
$0.50 \% \mathrm{MME}$ & $81.25^{\mathrm{c}} \pm 1.70$ & $79.5^{\mathrm{a}} \pm 2.46$ & $223.5^{\mathrm{a}} \pm 3.27$ & $5.62^{\mathrm{bc}} \pm 0.20$ \\
$0.75 \% \mathrm{MME}$ & $63.5^{\mathrm{a}} \pm 1.93$ & $66.5^{\dagger} \pm 1.93$ & $206.75^{\mathrm{e}} \pm 1.10$ & $4.52^{\mathrm{a}} \pm 0.23$ \\
$0.5 \% \mathrm{DM}$ & $96.5^{\mathrm{a}} \pm 1.7$ & $98.5^{\mathrm{b}} \pm 1.32$ & $270.75^{\mathrm{b}} \pm 2.63$ & $5.75^{\mathrm{b}} \pm 0.14$ \\
$1 \% \mathrm{DM}$ & $89.25^{\mathrm{b}} \pm 1.93$ & $84.5^{\mathrm{d}} \pm 2.78$ & $248.25^{\mathrm{c}} \pm 1.65$ & $5.67^{\mathrm{b}} \pm 0.11$ \\
$2 \% \mathrm{DM}$ & $82^{\mathrm{c}} \pm 1.68$ & $72.75^{\mathrm{e}} \pm 1.79$ & $230.25^{\mathrm{d}} \pm 2.52$ & $5^{\mathrm{cd}} \pm 0.15$ \\
\hline
\end{tabular}

Values are expressed as, Means \pm SE ; Means in the same column each group with different superscript letters are significantly difference $(p \leq 0.05)$ 
Egyptian J. of Nutrition Vol. XXXIII No. 1 (2018)

Table (3) :Effect of MME and DM on serum Alpha-fetoprotein , Glutathione (GSH) and Malondialdehyde (MDA) of liver cancer rats.

\begin{tabular}{l|c|c|c}
\hline \multicolumn{1}{c|}{ Parameters } & $\begin{array}{c}\text { Alpha-fetoprotein } \\
(\mathrm{ng} / \mathrm{ml})\end{array}$ & $\begin{array}{c}\text { Glutathione } \\
(\mu \mathrm{mol} / \mathrm{mg})\end{array}$ & $\begin{array}{c}\text { Malondialdehyde } \\
(\mu \mathrm{mol} / \mathrm{mg})\end{array}$ \\
\hline Control(-) & $6^{\mathrm{e}} \pm 0.50$ & $9.5^{\mathrm{a}} \pm 1.34$ & $3.63^{\mathrm{g}} \pm 0.88$ \\
Control $(+)$ & $27.5^{\mathrm{a}} \pm 1.32$ & $6.25^{\mathrm{ed}} \pm 1.02$ & $14.74^{\mathrm{a}} \pm 4.12$ \\
$0.25 \% \mathrm{MME}$ & $19.5^{\mathrm{b}} \pm 0.64$ & $6.41^{\mathrm{ed}} \pm 0.59$ & $11.6^{\mathrm{bc}} \pm 2.82$ \\
$0.50 \% \mathrm{MME}$ & $18.25^{\mathrm{bc}} \pm 0.85$ & $7.1^{\mathrm{da}} \pm 1.27$ & $8.56^{\mathrm{ed}} \pm 1.51$ \\
$0.75 \% \mathrm{MME}$ & $15^{\mathrm{d}} \pm 0.91$ & $8.27^{\mathrm{b}} \pm 1.39$ & $6.64^{\dagger} \pm 2.6$ \\
$0.5 \% \mathrm{DM}$ & $19.75^{\mathrm{b}} \pm 0.85$ & $6.3^{\mathrm{ed}} \pm 1.03$ & $12.3^{\mathrm{ab}} \pm 2.92$ \\
$1 \% \mathrm{DM}$ & $18.75^{\mathrm{bc}} \pm 0.85$ & $6.9^{\mathrm{d}} \pm 0.79$ & $8.72^{\mathrm{d}} \pm 1.7$ \\
$2 \% \mathrm{DM}$ & $16.5^{\mathrm{cd}} \pm 1.04$ & $7.82^{\mathrm{c}} \pm 1.44$ & $7.32^{\mathrm{et}} \pm 1.87$ \\
\hline
\end{tabular}

Values are expressed as, Means $\pm S E$; Means in the same column each group with different superscript letters are significantly difference $(p \leq 0.05)$. 
Aisha K . Abass, Mohammed M . El-Sayed, Sherif S. Rageb .
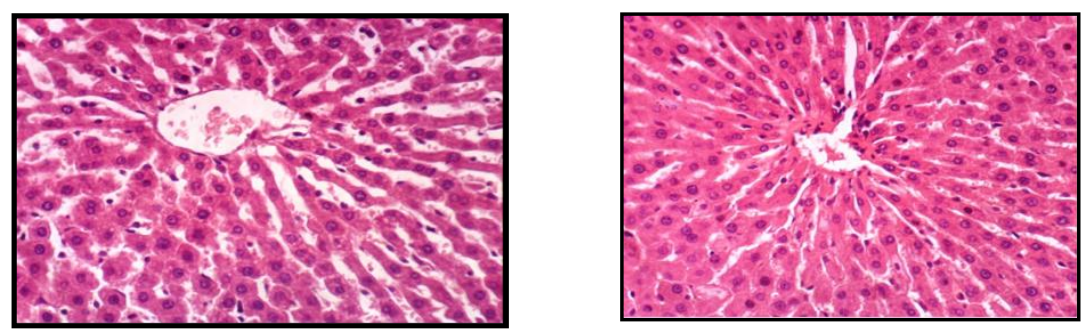

Picts. (1,2): Liver of rat from control negative group (H \& E X 400).
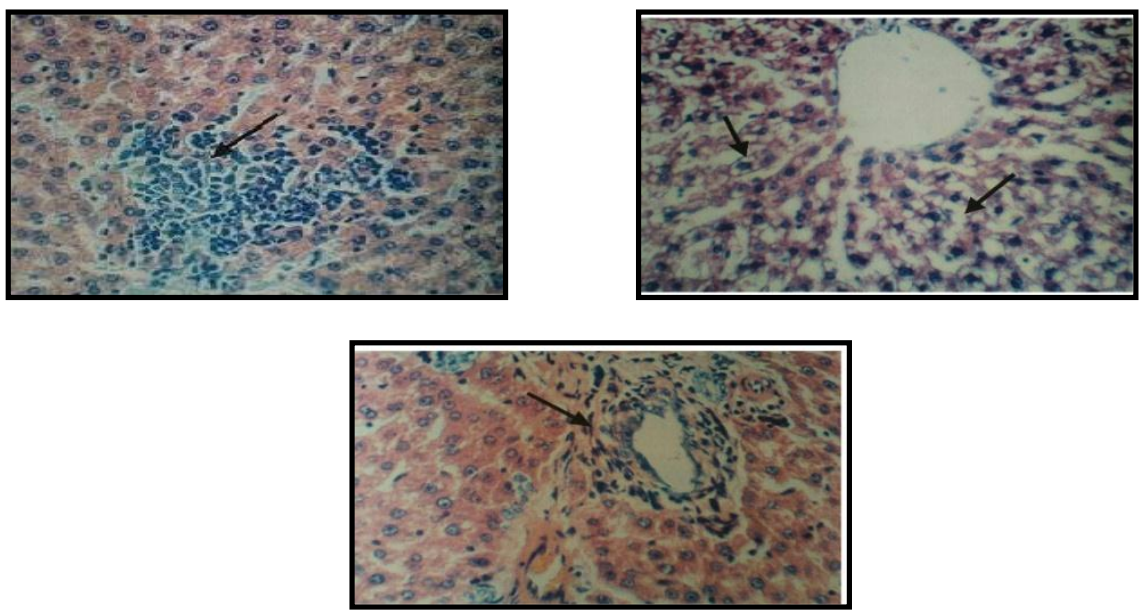

Picts. $(3,4,5)$ : Liver of rat from control positive group (H \& E X 400). 
Egyptian J. of Nutrition Vol. XXXIII No. 1 (2018)
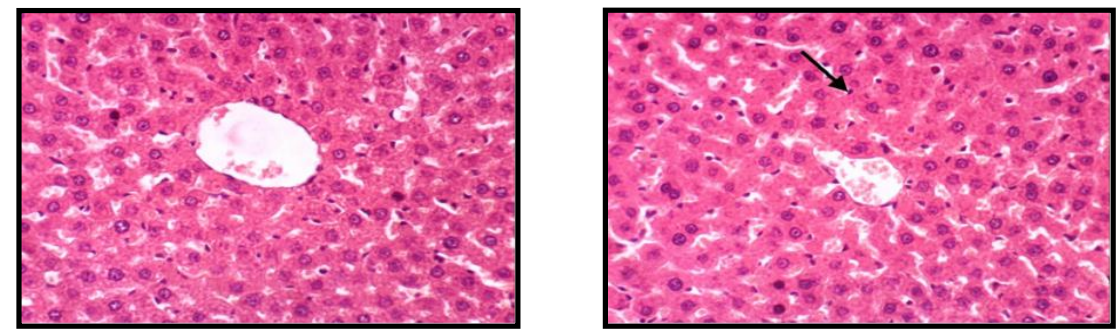

Picts. (6,7): Liver of rat from group 1 (0.25\% MME) (H \& E X 400).
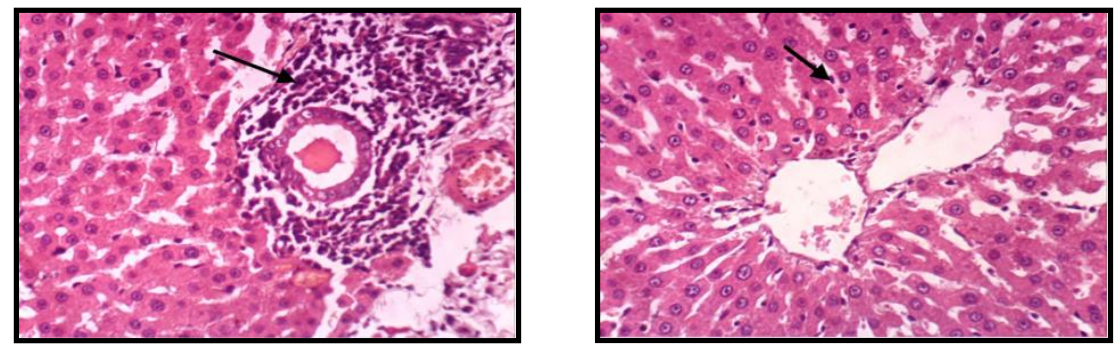

Picts. (8,9): Liver of rat from group 2 (0.50\% MME) (H \& EX 400).
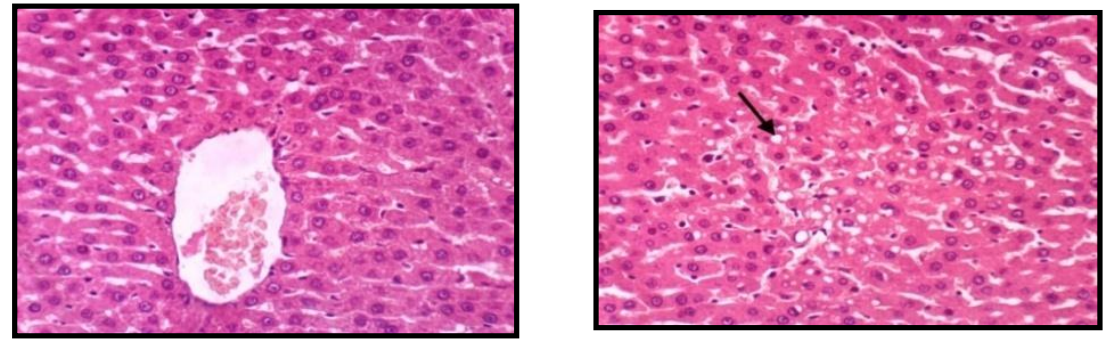

Picts. (10,11): Liver of rat from group 3 (0.75\% MME) (H \& E X 400). 
Aisha K . Abass, Mohammed M. El-Sayed, Sherif S. Rageb .
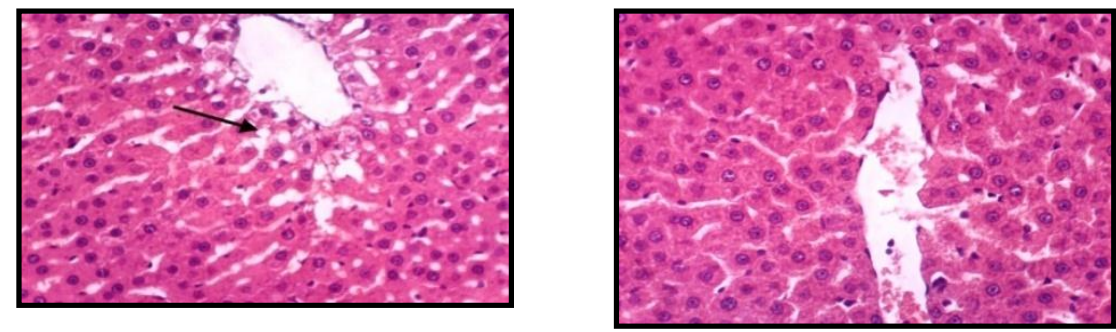

Picts. (12,13): Liver of rat from group 4 (0.5\% DM) (H \& E X 400).
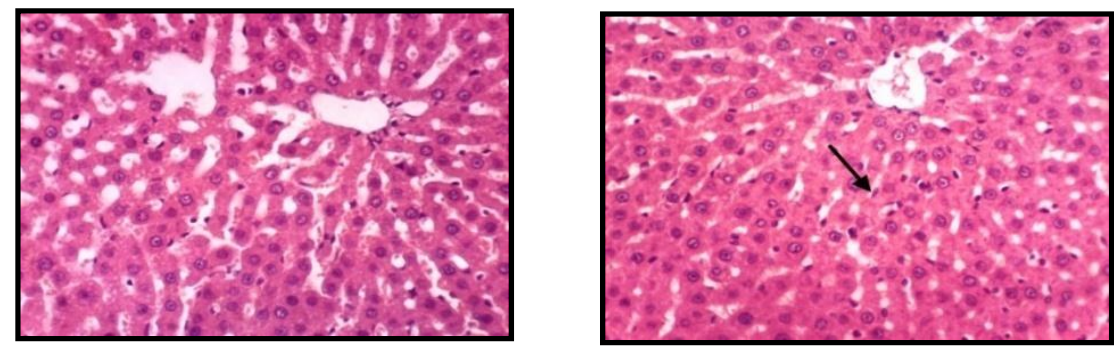

Picts. (14,15): Liver of rat from group 5 (0.1\% DM) (H \& E X 400).
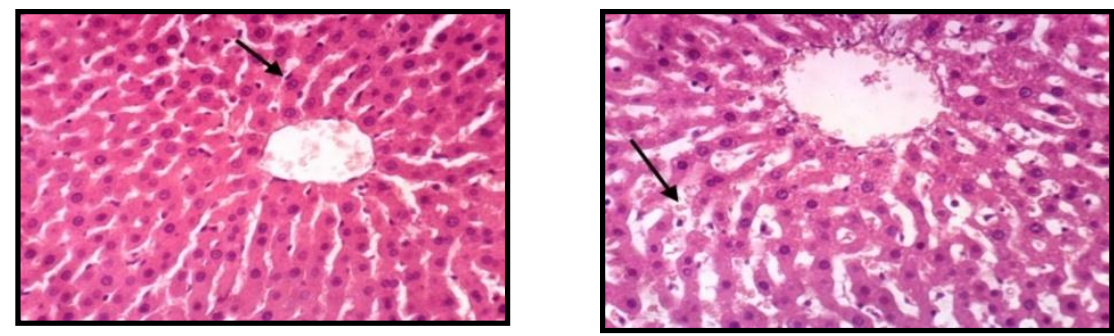

Picts. (16,17): Liver of rat from group 5 (0.1\% DM) (H \& E X 400). 
Egyptian J. of Nutrition Vol. XXXIII No. 1 (2018)

\section{References}

Ain, American Institute of Nutrition . (1993):

Purified Diet for Laboratory Rodent, Final Report. J. Nutrition, 123: 1939 - 1951 and O. Compactum Benth, J. Essential Oil Res., 8 (6): $657-664$.

\section{American Cancer Society(2013):}

Cancer Facts \& Figures. Atlanta, Ga: American Cancer activities: a short review. Food Chem Toxicol. 40: 1091-7.

Bosch , F.X ; Ribes, J. and Borras , J (1999):

Epidemiology of primary liver cancer. Semin Liver Dis., 19: 271-285.

Buege, J.A and Aust, S.D (1978):

Microsomal lipid peroxidation Methods Enzymol , 12:302-10. doi: 10.1016/S0076-6879(78)52032-6.

Campbell, J. A. (1963).:

Methodology of Protein Evaluation. RAG Nutr., Document R.10, Led. 37. June Meeting, New York.

Chapman, D. G.; Castilla, R. \& Campbell, J. A. (1959):

Evaluation of protein in food. I. A method for the deterinination of protein efficiency ration. Can.J. Biochem. Phosiol., 37: 679686.

Charai, M.; Mosaddak, M.; and Faid, M. (1996).

Chemical composition and antimicrobial activities of two aromatic plants (Origanum majorana,$L$ ) compactum. Journal of Essential Oil Research. 8(6): 657-664.

Drupt, F. (1974):

"Colorimetric method for determination of albumin." Pharm. Biol., 9: 777-779. 


\section{Aisha K . Abass, Mohammed M. El-Sayed, Sherif S. Rageb.}

Drury, R. A. and Wallington, E. A. (1967).

Carlton's Histological Technique. 5th Ed. Oxford Univ.

Drury, R. A. and Wallington, E. A. (1980).

Carlton's Histological Technique. 5th Ed. Oxford Univ.

Elhassaneen ,Y. (2002):

New and quickly biological method for detection the potential chemical toxins and/or carcinogens in foods. Proceedings of 2nd scientific Conference on Foodbome Contamination and Egyption's Health (24 - 24 April), Faculty of Agriculture, Mansoura University, Mansoura, Egypt, PP 371- 394.

Elhassaneen, Y.A. (1996).

Biochemical and Technological Studies on Pollution of Fish with Pesticides and Polycyclic Aromatic Hydrocarbons. Ph.D. Thesis., Faculty of Agriculture, Mansoura University, Egypt.

\section{Elhassaneen, Y.A. (2004).}

The effect of charcoal broiled meat consumption on antioxidant defence system of erythrocytes and antioxidant vitamins in plasma. Nutrition Research, 24 (6): 435 - 446.

\section{El-Safty ,A. (2008):}

Chemical, technological and nutritional studies on Marjoram (Marjoram Hortensis) M.Sc. Thesis in Nutrition and Food Science, Faculty of Home Economics, Minoufiya University, Egypt.

\section{El-Serag, H. (2011).}

"Hepatocellular Carcinoma". New England, J. Medicine. 365 (12): 1118 - 27.Salt mixture. J. Biol. Chem., 138: 459. 
Farazi, P.A and DePinho, R.A (2006):

Hepatocellular carcinoma pathogenesis: from genes to environment. Nat Rev Cancer, 6: 674-687.

Ghaly, H.M. (2004).

Biochemical and microbiological studies on some spives distributed in Egyptian markets. M.Sc. Thesis, Fac. of Home Economics, Minufiya University, Shebin El-Kom, Egypt.

Harttig, U.; Hendricks, J.D.; Stoner, G.D. and Bailey, G.S. (1996). Organ specific, protocol dependent modulation of 7,12dimethylbenz[a]anthracene carcinogenesis in rainbow trout (Oncorhynchus mykiss) by dietary ellagic acid. Carcinogenesis, 17 (11): 2403-2409.

Harvey, R.G., (1982).

Polycyclic hydrocarbons and cancer.Am. Sci., 80: 386.

Harvey, R.G., Ed (1985):

Polycyclic Hydrocarbons and Carcinogenesis. ACS Symp. Ser. 283, American Chemical Society, Washington, D.C., USA.

Hawkins, E.W.; Walker, W.W.; Overstreet, R.M.; Lytle, T.F. and Lytle, J.S. (1990):

Carcinogenic effects of some polycyclic aromatic hydrocarbons on the Japanese Medaka and Guppy in waterborne exposures. The Science of the Total Environment, 94: 155-167.

Hegsted, D.; Mills, R. and Perkins, E. (1941).

Salt mixture. J. Biol. Chem., 138: 459.

Henry, R. J; Cannon, D. C. and Winkehman, J. W. (1974):

Clinical Chemistry , Principles and Techniques. $2^{\text {nd }}$ Ed., Harper and Row. 


\section{Aisha K. Abass, Mohammed M. El-Sayed, Sherif S. Rageb .}

Howlader, N; Noone, A.M and Krapcho, M (2012):

SEER Cancer Statistics Review, 1975-2009(Vintage 2009 Populations), National Cancer Institute. Bethesda, MD, http://seer.cancer.gov/csr/1975_2009_pops09.

Ibrahim, M. El-Ashmawy,; Amal Saleh.; Osama, M. Salama. (2007):

Effect of Marjoram Volatile Oil and Grape Seed Extract on Ethanol Toxicity in Male Rats. BCPT, 101(5): 320-327.

Kumada, T; Nakano, S; Takeda, I; Sugiyama, K; Osada, T; Kiriyama, S; Sone, Y; Toyoda, H; Shimada, S; Takahashi ,M and Sassa, T(1997):

Patterns of recurrence after initial treatment in patients with small hepatocellular carcinoma. Hepatology, 25: 87-92.

Majid, S.; Khanduja, K.L.; Gandhi, R.K.; Kapur, S. and Sharma, R.R. (1991).

Influence of ellagic acid on antioxidant defense system and lipid peroxidation in mice. Biochemistry and Pharmacology Journal, 42(7): 1441-1445.

Mcfarris, M.W. and D.J. Reed, (1987):

HPLC of thiols and hisulfides : dinitro phenol derivatives. Methods Enzymol., 143: 101-109.

Miguel, M., G.; Guerrero, C.; Rodrigues, H.; Brito, J.; Duarte, F.; Venancio, F.; and Tavares, R. (2003).

Essential oils of Portuguese Thymus mastichina , (L.) L. subsp. mastichina grown on different substrates and harvested on different date. Journal-of-Horticultural-Science\&-Biotechnology. 78(3): 355-358. 
Egyptian J. of Nutrition Vol. XXXIII No. 1 (2018)

Novak, J.; Langbehn, J.; Pank, F.; and Franz, C., M. (2002).

Essential oil compounds in a historical sample of marjoram (Origanum majorana L.). Lamiaceae Flavour and Fragrance Journal. 17(3): 175-180 .

NRC, National Research Council. (1996).

National science education standards. Washington, D. C: National Academy Press.

Okuda, H (2007) :

Hepatocellular carcinoma development in cirrhosis. Best Pract Res Clin Gastroenterol, 21: 161-173.

SPSS, (1998):

Statistical Package For Social Science, Computer Software, Ver. 10, SPSS Company, London, UK.

Thomas, M.B (2008):

Systemic therapy for hepatocellular carcinoma. Cancer, J. 14: 123-127.

U.S. Environmental Protection Agency (2005):

Supplemental Guidance for Assessing Cancer Susceptibility from Early-Life Exposure to Carcinogens.

Vera, R.,R.; and Chane Ming, J.( 1999):

Chemical composition of the essential oil of marjoram (Origanum majorana, L.) from Reunion Island. Food Chemistry, 66(2): 143-145.

Yound, D. S. (1975):

Determination of GOT . J. Clin. Chem.; 21:1 . 
Aisha K . Abass, Mohammed M . El-Sayed, Sherif S.

Rageb .

تأثير بعض مستخلصات البردقوش علي سرطان الكبد الحادث بواسطة البنزوبيرين في الفئران

عائشة كامل عباس , محمد مصطفي السيد, شريف صبري رجب . قسم التظذية وعلوم الأطعة ـ كلية الاقتصاد المنزلى- جامعة المنوفيةـ شبين الكوممصر

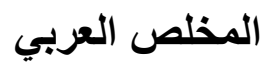

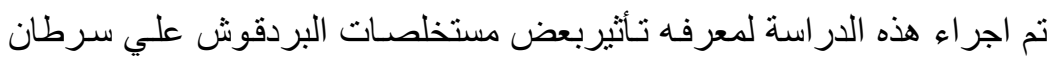

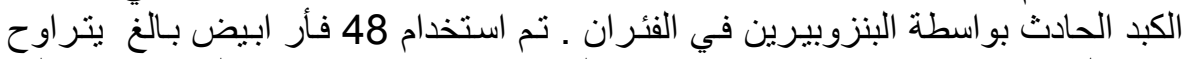

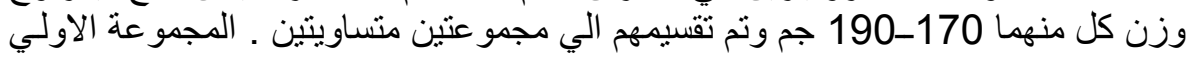

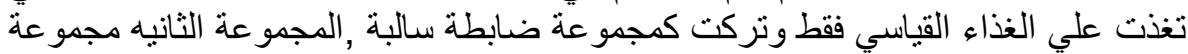

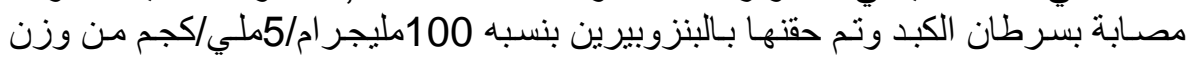

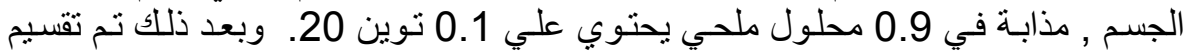

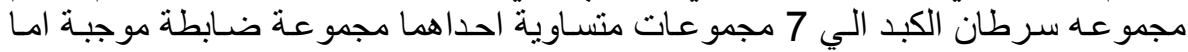

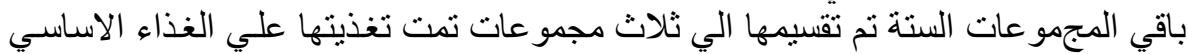

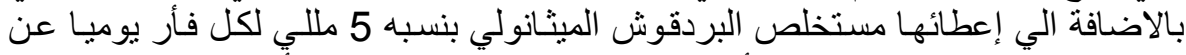

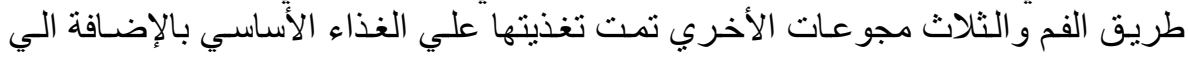

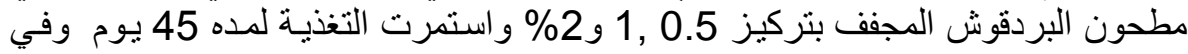
نهاية التجربة تم وزن الفئران ثم ذبحهم وتجمير

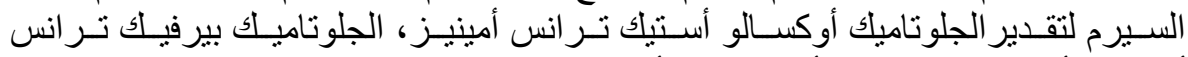

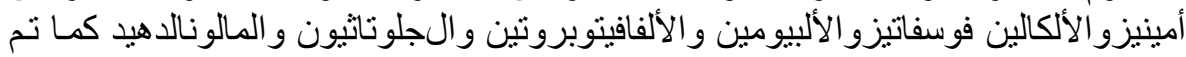

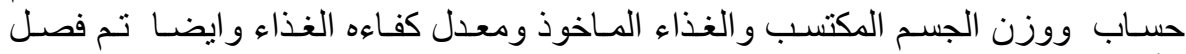

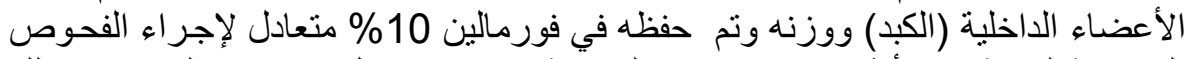

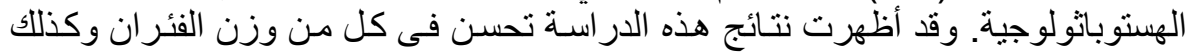

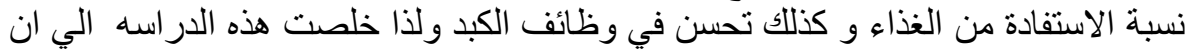

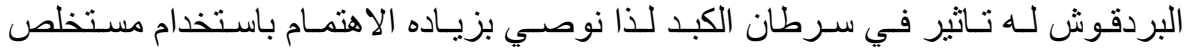
البردقوش والبردقوش ألمجف بكميات معتدله (0.75\% , 2\%) في وجباتتا ومشروباتنا 